\title{
Erratum to: An Uneven and Combined Development Theory of Law: Initiation
}

\author{
Susan Dianne Brophy ${ }^{1}$
}

\section{Erratum to: Law Critique \\ DOI 10.1007/s10978-017-9200-0}

The article title was incorrectly published in the original publication. The correct title is given in this erratum.

The original article was corrected.

The online version of the original article can be found under doi:10.1007/s10978-017-9200-0.

Susan Dianne Brophy

susan.brophy@uwaterloo.ca

1 Department of Sociology and Legal Studies, St. Jerome's University in the University of Waterloo, Waterloo, ON N2L 3G3, Canada 